\title{
Gari agar as culture media for mycological studies
}

\author{
S.I. OKORONDU ${ }^{1 *}$, C. O. AKUJOBI ${ }^{1}$, J.N. OKORONDU ${ }^{2}$ et M.M.O. OKORONDU ${ }^{3}$ \\ ${ }^{l}$ Department of Microbiology, Federal University of Technology Owerri, P.M.B. 1526, Owerri, Nigeria. \\ ${ }^{2}$ Department of Chemistry, University of Port Harcourt, P.M.B. 5323, Port Harcourt, Nigeria. \\ ${ }^{3}$ Department of Biochemistry, Federal University of Technology Owerri, P.M.B. 1526, Owerri, Nigeria. \\ *Corresponding author, E-mail: sokorondu@yahoo.co.uk
}

\begin{abstract}
Gari agar was prepared by weighing $28 \mathrm{~g}$ of Gari, $14 \mathrm{~g}$ of agar powder and $8 \mathrm{~g}$ of Hibiscus rabdariffa powder to $1 \mathrm{~L}$ of sterile water. A conventional media, Sabouraud Dextrose Agar (SDA) was prepared as control according to manufacturer's procedure. Aliquot of appropriate dilutions of $1 \mathrm{~g}$ of agricultural soil was inoculated onto SDA and Gari agar by pour plate technique and spread plate technique. After 2 days and 4 days of inoculation, the growth of moulds was examined. Fungal colonies on Gari agar were very healthy and compared favourably with fungal growth on Sabouraud dextrose agar which is a conventional medium. Gari agar produced healthy moulds as determined by diameter of growth. Furthermore, conventional media (SDA) supported the growth of bacteria while Gari agar inhibited the growth of bacteria and promoted that of fungi. Cassava can be successfully grown in poor soils with low labour requirement, low capital and ease of cultivation. Gari extract agar can now be used successfully for quantitative count of moulds. The result of this study will go a long way in solving the problem of high cost of conventional media used as culture media for mycological studies.
\end{abstract}

(c) 2013 International Formulae Group. All rights reserved.

Keywords: Gari agar, Hibiscus rabdariffa, Sabouraud Dextrose agar, quantitative count, moulds, cassava.

\section{INTRODUCTION}

Gari, a fermented cassava product, is widely consumed in many West African Countries. Gari is produced from cassava by fermenting grated pulps, followed by dewatering, sieving and roasting (Coursey, 1973). Cassava is a staple food in Nigeria, consumed by all tribes. Its propagation is very easy and requires small capital and less labour. Propagation is by stem cuttings of about $8 \mathrm{~cm}$. The yield per stem cutting is very high (Okorondu et al., 2009). Cassava has an outstanding ecological adaptation, accounting for its being widely cultivated around Nigeria and West Africa and can be successfully grown on poor soils. Nigeria is the world's largest producer of cassava. Cassava is the staple food for at least 500 million people (Cock, 1985). Since introduced by portuguese traders from Brazil in the $6^{\text {th }}$ century, maize and cassava have replaced traditional African crops as the continent's most important staple crops (Adams et al., 2009).

From the time agar was introduced as a solidifying agent for mycological media in 1883, agar was found to have such desirable 
characteristics that it has not been replaced over 100 years. Agar dissolves at $100{ }^{\circ} \mathrm{C}$ and solidifies at $45^{\circ} \mathrm{C}$ (Pelcazar et al., 1986).

Studies of the structure characteristics of moulds could be simplified by placing on microscope slide small blocks of agar $(1 \mathrm{~cm}$ square) cut from poured plates of appropriate culture media; the upper edge of the agar blocks are inoculated with the desired moulds; then after adequate incubation of inoculated blocks, the slides on which the blocks were placed are examined under the microscope (Smith, 1969; Beisha, 1987). This is because moulds, being among the largest microorganisms studied, can be identified to generic level often without special staining or biochemical technique since their structural details could be readily visible microscopically. It is to be noted, however that structural differences are readily observed only if the moulds colony is not disturbed during preparation or mounting for microscopic examination (Beisha, 1987), and this is achieved by means of micro cultures on microscope slides (Sokari et al.,1996).

In Nigeria setting, Gari is far more easily available and cheaper than conventional mycological media. Gari granules have been used as adequate substrate for growth of moulds, allowing for details of structure that are readily differentiable by means of optional microscope (Sokari et al., 1996). Gari in its native processed form using hot water (Eba) cannot be used in quantitative counts requiring a high degree of numerical accuracy (Sokari et al., 1996). Gari extract agar is now used successfully in quantitative count with numerical accuracy as well as for mycological studies (Okorondu et al., 2011).

Potato dextrose agar is recommended by the American public health association for plate count of yeasts and moulds in the examination of food and dairy products (Son et al., 2001). It is recommended in the USP for use in the performance of Microbial Limit
Tests (Lee et al., 2000). It is also used for the stimulation of sporulation (slide preparation), maintenance of stock cultures of certain dermatophytes and for differentiation of atypical varieties of dematophytes by pigment production (Yang et al., 2001). However Potato Dextrose agar and Sabouraud Dextrose agar supports the growth of bacteria unless an antibiotic is incorporated in the medium.

The aim of this study therefore was to use Gari agar as a culture medium for quantitative counts as well as for other mycological studies.

\section{MATERIALS AND METHODS \\ Source of sample and preparation of Gari agar}

Gari was bought from mile 3 market in Port Harcourt, Rivers State, Nigeria. The Gari was ground with a blender to give very fine particles. It was sieved with a sterile muslin cloth to make the particles finer and smooth. Gari agar was prepared by weighing $28 \mathrm{~g}$ of Gari, $14 \mathrm{~g}$ of agar powder and $8 \mathrm{~g}$ of Hibiscus rabdariffa powder to $500 \mathrm{ml}$ of sterile water in $1 \mathrm{~L}$ flask and made up with same water to 1 $\mathrm{L}$ mark in a conical flask. This mixture was autoclaved at $121{ }^{\circ} \mathrm{C}$ for $15 \mathrm{~min}$ and allowed to cool to $45{ }^{\circ} \mathrm{C}$. At this temperature, it was poured into Petri dishes and allowed to solidify.

\section{Preparation of Sabouraud Dextrose Agar (SDA) \\ The commercial SDA media was prepared according to manufactures instruction. Thirty and half grams (30.5 g) of SDA was dissolved in $250 \mathrm{ml}$ of distilled water in $500 \mathrm{ml}$ conical flask, sterilized at 121 ${ }^{\circ} \mathrm{C}$ for $15 \mathrm{~min}$, cooled to $45^{\circ} \mathrm{C}$ and poured into Petri dishes.}

\section{Isolation of moulds using Gari agar (GA)}

One gram ( $1 \mathrm{~g})$ of agricultural soil was added to $9 \mathrm{ml}$ of sterile water and serial 
dilution up to $10^{-7}$ was made. An aliquot of the dilutions $(1 \mathrm{ml})$ was inoculated onto the prepared Gari agar, incubated for 2 and 4 days at $28{ }^{\circ} \mathrm{C}$ using Gallenkamp Incubator. Fungal colonies were purified and stored at the temperature of $4{ }^{\circ} \mathrm{C}$ for further use.

\section{Metal analysis of Hibiscus rabdariffa and Gari using atomic absorption spectrophometer (NetalCapha D3110)}

Metal analysis was carried out in an Atomic Absorption Spectrophotometer using acid digestion method of sample preparation, followed by filtration through a 0.45 micro membrane filter. Aliquots of the filtrate were used for analyses of the various metals (APHA, 1985).

\section{Sample digestion}

Three grams ( $3 \mathrm{~g})$ each of the ash sample was digested with $5 \mathrm{ml}$ of nitric acid to a minimum value of about $5 \mathrm{ml}$. The digest was filtered through a whatman No.44 filter paper directly into acid washed and well rinsed plastic container and was made up to $50 \mathrm{ml}$ mark in a volumetric flask. A reagent blank using $5 \mathrm{ml}$ of nitric acid was also incorporated.

\section{Instrumental analysis}

The heavy metals were determined using a flame atomic absorption spectrophotometer SOLAAR $32 \mathrm{AA}$ and using the appropriate hollow cathode lamp and resonance wavelength of the metals.

Metal Concentration $(\mathrm{mg} / \mathrm{kg})=\frac{(x-y) V_{1}}{V_{2}}$,

Where $\mathrm{x}=$ concentration of metals obtained from atomic absorption spectrophotometer for sample $(\mathrm{mg} / \mathrm{l})$

$\mathrm{y}=$ Concentration of metal obtained from atomic absorption spectrophotometer instrument for blank
$\mathrm{V}_{1}=$ Volume of digest sent for analysis $(\mathrm{ml})$

$\mathrm{V}_{2}=$ weight of ash sample $(\mathrm{g})$

\section{Proximate laboratory analysis of Hibiscus rabdariffa and Gari}

Selected physical and chemical properties were determined in the laboratory. The physical properties determined were Moisture content, Ash content, Crude Fat (Ether content), while the chemical properties were crude fibre, crude protein. These were carried out according to official methods of Analysis of the Association of Official Analytical chemists (AOAC, 1984).

\section{RESULTS AND DISCUSSION}

Gari agar was successfully used for isolation of moulds from agricultural soil sample. Gari mixed with agar powder and Hibiscus rabdariffa gave a beautiful red colour background and produced healthy moulds probably because of additional nutrients from the Hibiscus rabdariffa which was also used as colorant. The fungi isolated from the soil include Aspergillus niger and Aspergillus oryzae. The growths of these organisms were impressive (Figures 1 and 2). Quantitative counts on Gari extract agar showed discrete colonies as is the case with conventional media such as Sabouraud dextrose agar (Okorondu et al., 2011). The cultural and morphological details of fungal growth on Gari agar were greatly enhanced. The growth of Rhizopus stolonifer and Aspergillus oryzae on the Gari agar compared favourably with that on Sabouraud dextrose agar (Figures 1 and 2). The $\mathrm{pH}$ of Gari agar lies between 4.0 and 4.2; Gari being a little acidic, contributed to this $\mathrm{pH}$ value and supported the growth of fungi but inhibited the growth of bacteria, however fungi grows well at this pH (Okorondu et al., 2011). Sabouraud dextrose agar supports the growth of bacteria, while Gari agar at $\mathrm{pH} 4.0$ to 4.2 inhibits the growth of contaminant bacteria. 
This might be attributed to the fact that contaminant bacteria cannot grow at this $\mathrm{pH}$ (4.0 to 4.2) (Okorondu et al., 2011). Proximate analysis of Hibiscus rabdariffa (Figure 3) showed 2\% fat, $8 \%$ ash, $7 \%$ fibre, $22 \%$ moisture content, $46 \%$ carbohydrate and $15 \%$ protein, while that of Gari (Figure 4) showed $1 \%$ crude protein, $2 \%$ fat, $1 \%$ ash, $3 \%$ fibre, $12 \%$ moisture content and $81 \%$ carbohydrate. The result revealed that Gari is nutritious and has all it takes to support the growth of fungi. Gari is widely known in Nigeria and other West African countries, it is however highly rich in carbohydrate, low in fat and protein. The addition of Hibiscus rabdariffa improved the nutritional value of Gari agar thereby contributing to fungal nutrition. Table 1 shows fungal count on Sabouraud dextrose agar (SDA) and Gari agar respectively. At $10^{-3}$ serial dilutions, there was no discrete colony to count in both SDA and Gari agar while at $10^{-5}$ and $10^{-6}$ serial dilutions, counts were $3 \times 10^{5}$ and $1 \times 10^{6}$ for both SDA and Gari agar respectively. This further proved Gari agar as alternative, cheaper and readily available media for mycological studies. The metal analysis of Gari and Hibiscus rabdariffa in Table 2 showed that Gari contains $1724.61 \mathrm{mg} / \mathrm{kg}$ of Potassium and Calcium $1576.06 \mathrm{mg} / \mathrm{kg}$, good amount of Sodium $732.60 \mathrm{mg} / \mathrm{kg}$, Iron 541.61 $\mathrm{mg} / \mathrm{kg}$, Zinc $250.60 \mathrm{mg} / \mathrm{kg}$ and Magnesium $834.13 \mathrm{mg} / \mathrm{kg}$, whereas Hibiscus rabdariffa contains $325.00 \mathrm{mg} / \mathrm{kg}$ of magnesium, 146.70 $\mathrm{mg} / \mathrm{kg}$ of Iron, potassium $108.42 \mathrm{mg} / \mathrm{kg}$, $1,309.30 \mathrm{mg} / \mathrm{kg}$ of calcium, $144.50 \mathrm{mg} / \mathrm{kg}$ of sodium, and $37.20 \mathrm{mg} / \mathrm{kg}$ of Zinc. According to Smith (1969), Pelczar (1986) and Pelcazar et al. (1986), the chemical elements essential for the growth of fungi are carbon, oxygen, nitrogen, potassium, magnesium, hydrogen, sulphur, and phosphorus, with some other metallic elements like iron needed in minute quantity by most fungi. This could explain why fungal growth on Gari agar was favourable and successful. Analysis of microbial cell composition shows that over $95 \%$ of cell dry weight is made up of a few major elements: carbon, oxygen, hydrogen, nitrogen, sulphur, phosphorus, potassium, calcium, magnesium, and iron (Wiley et al., 2008). These are called macroelements or macronutrients because they are required by microorganisms in relatively large amounts. The first six $(\mathrm{C}, \mathrm{O}, \mathrm{H}, \mathrm{N}, \mathrm{S}$, and $\mathrm{P})$ are components of carbohydrates, lipid, proteins, and nucleic acids. The remaining four macroelements exist in cell as cations and play a variety of roles. Potassium $\left(\mathrm{K}^{+}\right)$is required for activity by a number of enzymes, including some of those involved in protein synthesis. Calcium $\left(\mathrm{Ca}^{2+}\right)$, among other functions, contributes to the heat resistance of bacterial endospores. Magnesium $\left(\mathrm{Mg}^{2+}\right)$ serves as a cofactor for many enzymes, complexes with ATP, and stabilizes ribosomes and cell membranes. Iron $\left(\mathrm{Fe}^{2+}\right.$ and $\left.\mathrm{Fe}^{3+}\right)$ is part of cytochromes and a cofactor for enzymes and electron-carrying proteins (Wiley et al., 2008). Gari and Hibiscus rabdariffa are rich in these essential macronutrients and can be used in making culture media (Gari agar) to be used in quantitative counts as well as for other mycological studies as demonstrated in this study. 
S. I. OKORONDU et al. / Int. J. Biol. Chem. Sci. 7(3): 1126-1134, 2013
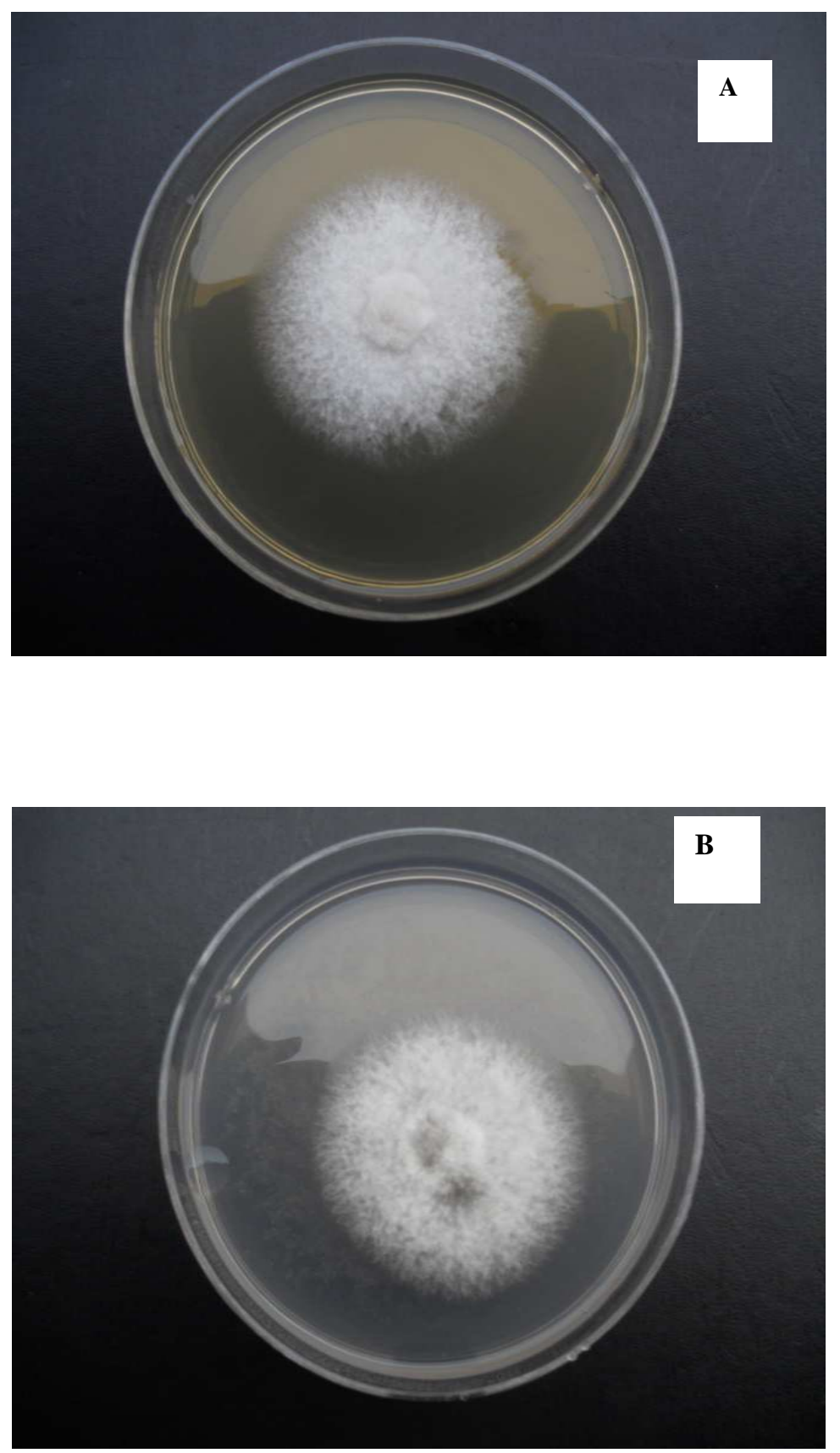

Figure 1: Rhizopus stolonifer on (A) Sabouraud dextrose agar and (B) Gari agar (2 days) days). 

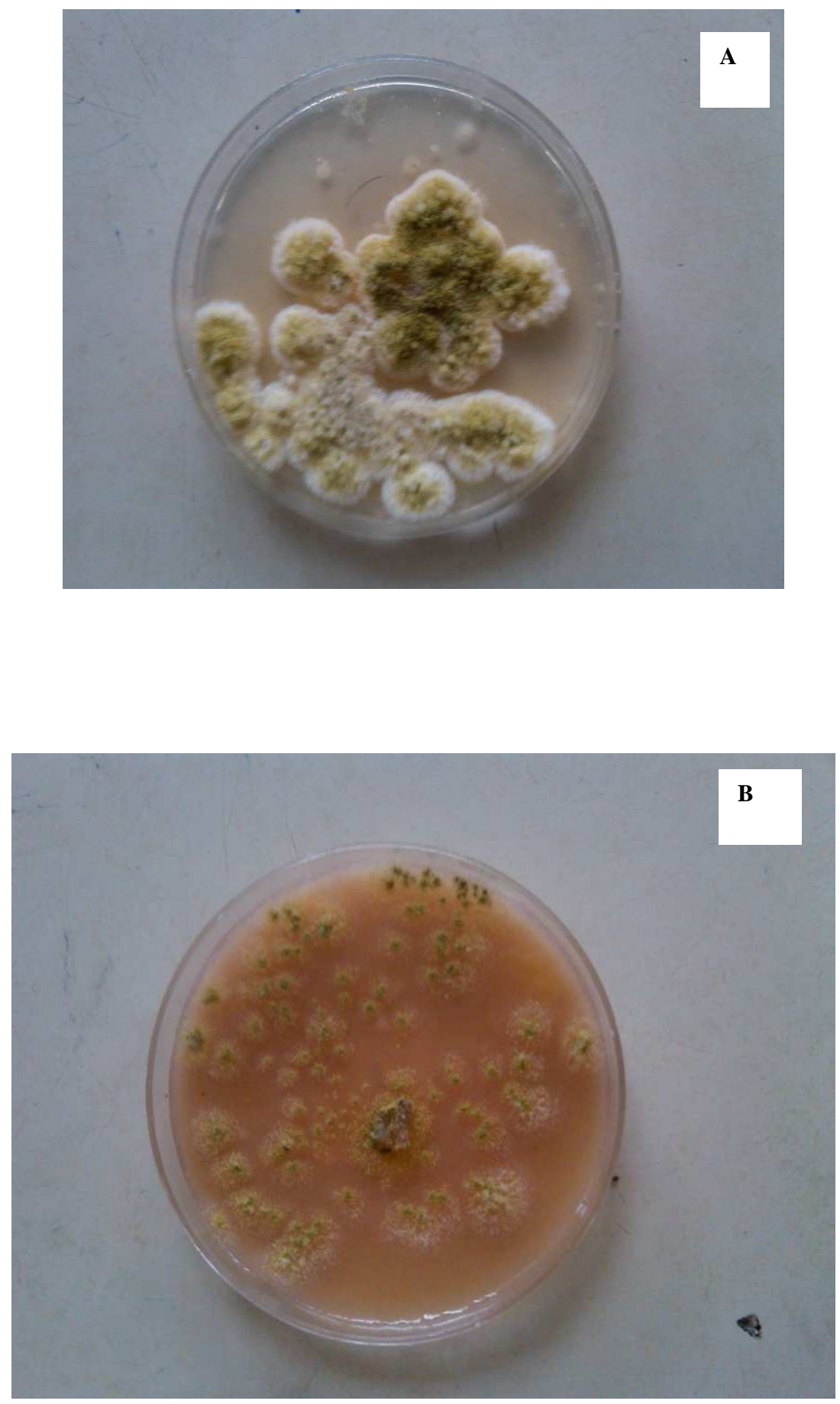

Figure 2: Aspergillus oryzae on (A) Sabouraud dextrose agar and (B) Gari agar (4 days). 


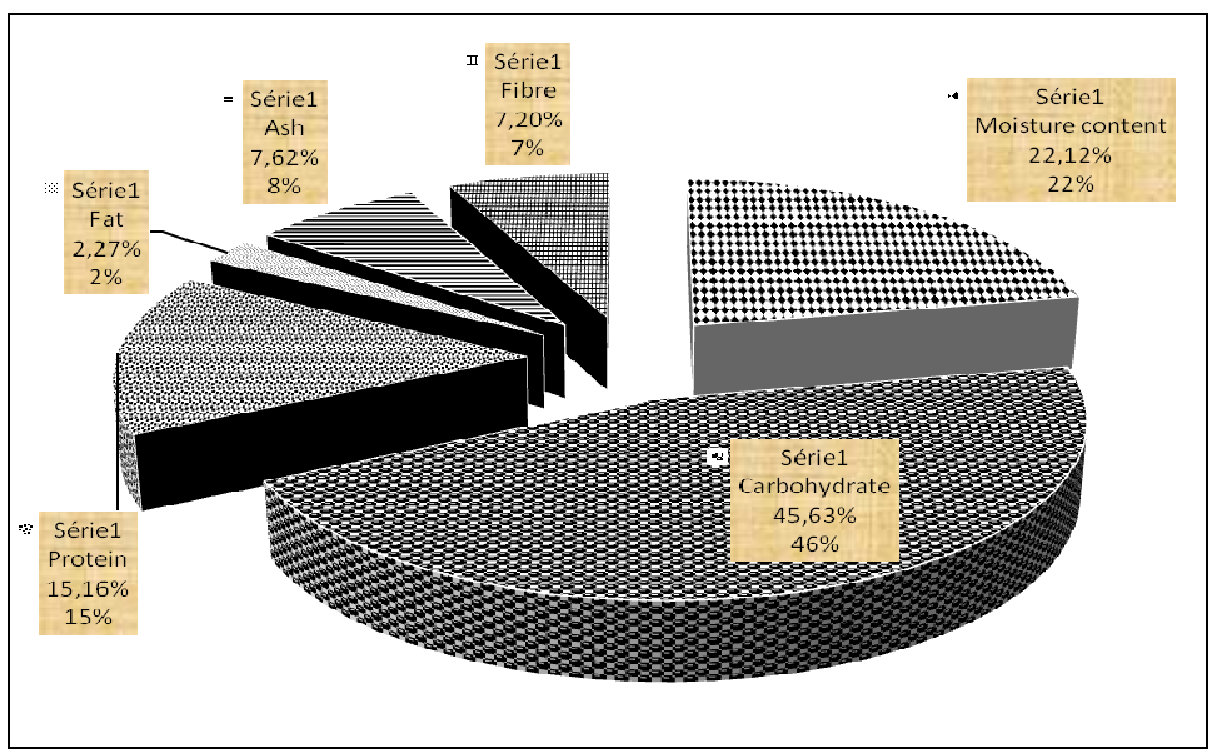

Figure 3: Proximate laboratory analysis of hibicus rabdariffa in percentage.

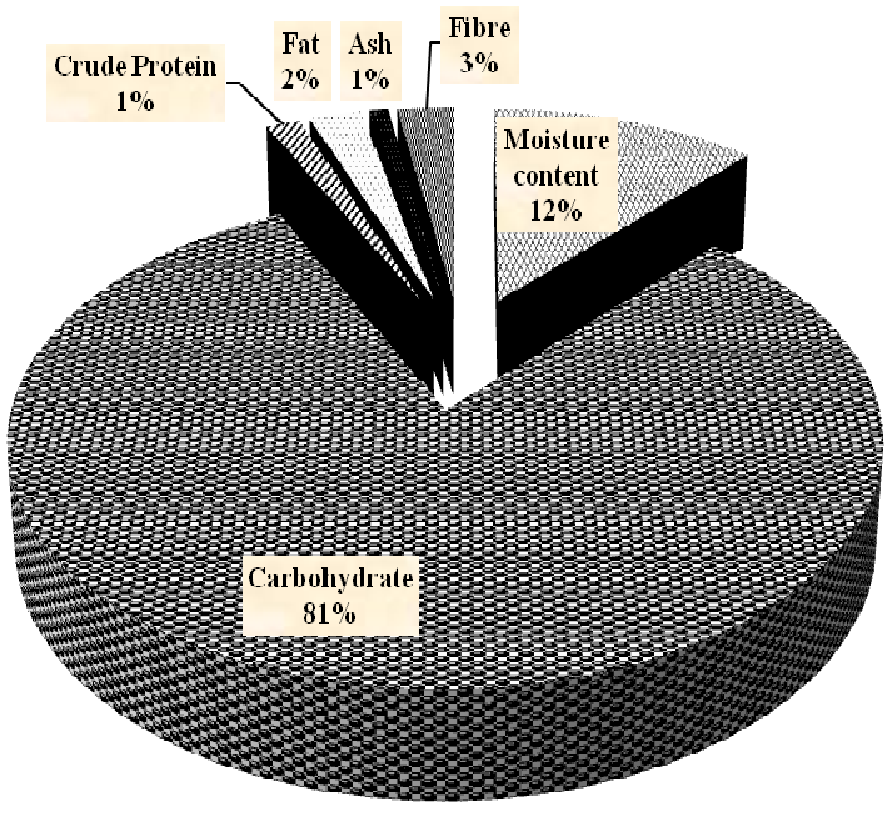

Figure 4: Proximate laboratory analysis of white Gari in percentage. 
Table 1: Fungal count in $1 \mathrm{~g}$ of agricultural soil.

\begin{tabular}{lcc}
\hline Serial Dilution & Gari Agar & SDA \\
\hline $10^{-3}$ & NDC & NDC \\
$10^{-5}$ & $3 \times 10^{5}$ & $3 \times 10^{5}$ \\
$10^{-6}$ & $1 \times 10^{6}$ & $1 \times 10^{6}$ \\
$10^{-7}$ & $\mathrm{NG}$ & $\mathrm{NG}$ \\
\hline \multicolumn{2}{r}{$\mathrm{NDC}=$ No discrete colony; NG= No growth; SDA= Sabouraud dextrose agar. }
\end{tabular}

Table 2: Metal analysis of Gari and Hibiscus rabdariffa (Average of 3 readings).

\begin{tabular}{lcccccc}
\hline Sample & \multicolumn{7}{c}{ Parameters (mg/kg) } \\
\cline { 2 - 7 } & Fe & Mg & K & Ca & Na & Zn \\
\hline Gari & 541.61 & 834.13 & 1724.61 & 1576.06 & 732.60 & 250.60 \\
Hibiscus rabdariffa & 146.70 & 325.00 & 108.42 & $1,309.30$ & 144.50 & 37.20 \\
\hline \multicolumn{2}{c}{ Fe, Iron; Mg, Magnesium; K, Potassium; Ca, Calcium; Na, Sodium; Zn, Zink. }
\end{tabular}

\section{Conclusion}

Gari agar supported the growth of fungi and inhibited the growth of bacteria. Fungal colonies on Gari agar were very healthy and conspicuous and compared favourably with fungal growth on a conventional medium (Sabouraud dextrose agar). Gari can be used successfully for quantitative count of fungi. The discovery of Gari agar has provided a less expensive alternative to expensive conventional media used as culture media for mycological studies. Gari agar is therefore recommended as culture media for quantitative counts of fungi as well as for other mycological studies.

\section{REFRENCES}

Adams C, Murrieta R, Siqueria A, Neves W, Saches R. 2009. Bread of the Land the Invincibility of Manioc in the Amazon. Amazon Peasant Societies in a changing Environment; 281-305.

APHA (American Public Health Association). 1985. Standard Methods for the Examination of Water and Waste Water $\left(16^{\text {th }}\right.$ edn). APHA:Washington, D.C.
AOAC (Association of Analytical Chemists). 1984. Official Methods of Analysis $\left(13^{\text {th }}\right.$ edn). AOAC: Virginia.

Beishir L. 1987. Microbiology in Practice. A Self-Instructions Laboratory Course $\left(4^{\text {th }}\right.$ edn). Harper and Row Publisher: New York; 120-130.

Cock JH. 1985. Cassava: New Potentials for a Neglected Crop. Westview Press: Boulder and London.

Coursey DG. 1973. Cassava as Food: Toxicity and Technology in Chronic Cassava Toxicity, Nestel BL, Macintyr R (eds). International Development Research Center: Ottawa, Canada; 27-36.

Lee PC, Lee WG, Kwon S, Lee SY and Chang HN. 2000.) Batch and continuous fermentation of succinic acid from whey by Anaerobiospirillum succiniciproducens, Applied Microbiology and Biotechnology, 54: 23-27.

Okorondu SI, Nedosa IV, Wesley B, Akujobi CO. 2009. Ethanol Production from Cassava. Current Trend in Biotechnology, 5: $65-70$.

Okorondu SI, Sokari TG, Akujobi CO, Ogbulie JN. 2011. Gari extract agar as a culture media for mycological studies. 
Current Topics in Biotechnology, 6: 3539.

Pelcazar JR MJ, Chan ECS, King NR. 1986. Microbiology $\left(5^{\text {th }}\right.$ edn) McGraw Hill Book Co.: Singapore.

Smith G. 1969. An Introduction to Industrial Mycology $\left(6^{\text {th }}\right.$ edn), Edward Arnold Publishers Ltd.: London; 239-240.

Sokari TG, Yubedee AG, Lugbe PB. 1996. Gari as an effective medium for certain mycological studies. Niger Delta Biologia, 1(1): 86-89.

Son H, Heo M, Kim Y, Lee S. 2001. Optimization of fermentation conditions for theproduction of bacterial cellulose by a newly isolated Acetobacter.
Biotechnology and Applied Biochemistry, 33(1): 312- 316.

Wiley JM, Sherwood LM, Woolverton CJ. 2008. Microbiology, Prescott, Harley, Klein's (eds). McGraw-Hill International edition.

Yang CD, Takeyama H, Tanaka T, Matsunaga T. 2001. Effects of growth medium composition, iron sources and atmospheric oxygen concentrations on production of luciferase-Bacterial magnetic particle complex by a recombinant Magnetospirillum magneticum AMB-1. Enzyme Microbiol Tech., 29:13-19. 